«Keruen» scientific journal

M.O.Auezov Institute of Literature and Art

ISSN 2078-8134

Volume 2, Number 71 (2021)

https://doi.org/10.53871/2078-8134.2021.2-01

IRTSI 17.07.41

\author{
Sultan Y. \\ M.O. Auezov Institute of Literature and Art \\ Leading researcher, $\mathrm{PhD}$, \\ Almaty, Kazakhstan \\ E-mail: yertaysultan@gmail.com \\ ORCID: 0000-0003-3240-2744
}

\title{
Modern Kazakh novels: the genre transformation
}

\begin{abstract}
This article discusses and analyzes the modern novel form, which went beyond the classical criteria. In particular, according to the works of such authors as T. Abdikov "Parasat Maidany", M.Magauin "Zharmak" and D.Amantay "Flowers and books", a genre modification of the modern novels is defined. As a result of the analysis of the works of contemporary writers, original tricks, and techniques for the transmission of modern reality by each author have been revealed. So, T.Abdikov resorts to a diary narrative, using for his artistic purposes it's "confessional", "reflective" function, which helps to reveal the character and creates the illusion of the authenticity and truthfulness of the depicted reality, and M.Magauin uses the paradigm of duality reflected in Western literature in the works of A. Camus, Z. Freud, C.-G. Jung. Thus, M.Magauin rises to the philosophical generalization of modern reality in the postmodern image. D. Amantay completely withdraws from the traditional forms of narration, tries to reveal the contradictory essence of modern reality.
\end{abstract}

Key words: kazakh prose, novels, genre modification, novel transformation

Introduction. Modern forms of the novel regulate going beyond the classical criteria. The modern novel is looking for a new form in which it could perceive and embody the relationship between people, between man and thing, the hero and time. Although there is no absolute novelty, since the novel is substantively fueled by its epoch, a certain literary tradition.

As M. Bakhtin notes, "the novel parodies other genres (precisely as genres), exposes the conventionality of their forms and language, displaces certain genres, others introduces into its own structure, reinterpreting and re-evaluating them" (Bakhtin, 1979). According to the researcher, this is a natural process of development of any genre.

The process of transformation, assuming a local change within the genre, creates more complex entities that can best convey the complexity of modern reality. Some scientists under the transformation mean the re-creation of the structure of the genre, thereby confirming its complete destruction. In our opinion, the transformation not only enriches the genre, but also allows a new transfer of problems that are of concern to authors.

A notable phenomenon of the new literature in Kazakhstan was the release of D. Amantay "Gulder men Kitaptar" (Flowers and Books) (Amantay, 2003), T. Abdikov's "Parasat Maidany" (The Burning War of the Mind) (Abdikov, 2003), M. Magauin's "Zharmak" (The Half) (Magauin, 2008) and others. They stand out for their eccentricity in stylistic, ideological and genre diversity.

Discussion. The author resorts to a diary narrative, using for artistic purposes its "confessional", "reflective" function, which helps to reveal the character and creates the illusion of the authenticity and truthfulness of the depicted reality. For this work, T. Abdikov was awarded the prestigious F. Kafka Prize.

The protagonist of the work is a patient of a psychiatric clinic. The narrator accidentally gets 
into his hands diary entries of the main character, which he presents to the reader's court. Sincerity, introspection, the image of the hero "from within" are working to create a tragic image. The author does not give a nominal name to his hero, only describes his character, external data:

«Түрі де есімде: ұзын бойлы, арық, ақ сары жігіт... Сөйлеген сөзінен, жүріс-тұрысынан зиялы от басынан шыққаны, кітаби тәрбиені көбірек көргені байқалады. Мінезі жұмсақ» (Abdikov, 2003: 4).

Feelings, experiences, reflections of the hero, expressed in his letters and diary entries, fill the whole work. In the "dialogic conflict" between the heroes dominated the hero-narrator, who is destined to put an end. The bright emotional coloring of the narrative makes the reader become more fully absorbed by the tragic feelings of the character about the modern person and time. Noticeable at first glance, the futility of the work actually hides the intricate problem of the essence and meaning of life, the role of man in modern society. The work once again convinces that man and his essence are still a mystery, which cannot be solved by philosophers, writers, or anyone else.

Already in the title of the work, there is a certain initial opposition of the sides. In this case, dualism inherent in the aesthetics of modernism is guessed in the inner psychological structure of the main character. The person writing polemical letters to the patient of the clinic turns out to be his own other "I". The hero does not immediately known about the existence of his other "I". Opposition to himself, exhausting conflict with yourself unfold on the level of consciousness of the protagonist.

In the opinion of A.K. Ishchanova, in accordance with the old traditions of Russian and world literature in T. Abdikov's work, the motif of the inner split of the personality deepens, which in itself is a sign of a deep crisis of the consciousness of modern man. "In the Kazakh writer's work suffer from a split not the worst, but the best of people, feeling the anguish of the increased imperfection of the world and man" (Ishanova, 2005: 122).

Good and evil, life and death, loneliness, fear, freedom, sin, guilt, lies and truth provoke in the character's soul a dialogue, a polemic with another "I". One side of the soul acts as a prosecutor, and the other - in the role of a lawyer. The antithesis of opinions is shaded by letters that the hero finds in his own room. These messages deprive him of a quiet sleep. He is constantly haunted by the thought of a stranger who is watching him. An easy detective plaque strengthens the mystery of the hidden twin, with the worldview of which the reader is acquainted by his letters.

The theme of duality in new ways disclosed in the last novel by M. Magauin "Zharmak". A double is, as a rule, a recognizable image of himself - the other, an image that with the true essence never coincides. The emergence of ambivalent characters in the work of well-known Kazakh writers is connected with the fundamental contradictions of modern social reality. Therefore, modern novels are increasingly characterized by a tragic or dramatic collision.

At the beginning of the work M. Magauin reveals the idea and process of creating this novel. From the very first lines one can understand that the duality complex was also laid down at the level of the author-narrator's consciousness. The writer finds the archive records of Iman Kazakbaev, who intend to publish. However, as shown in the novel, the name of the unknown writer is not taken seriously by the editors. Based on these records, M. Magauin writes a work, which, as we see, belongs not only to his pen. The paradigm of duality makes itself felt in the title of the work. The author offers the reader different names, explains the meaning of the probable word "zharmak" (the half):

«Айтпақшы, хикаятымыздың әуелгі, тума атауы - «Қилы тағдырлар» екен. Одан соң «Көлеңке», «Сыңар», «Астар»... Ақыры «Сүлде». Біз еш қайсысын мақұл таппадық. Бәрі де жөн, бірақ тақырыпты толық қамтымайды. Сондықтан өз тарабымыздан басқаша атауды жөн көрдік. «Жармақ». Яғни, бүтіннің бөлшегі. Екінші жарымы» (Magauin, 2008: 8).

Disclosure by the author of the tragic aspects of man's spiritual existence of his own age is such a philosophical and moral-psychological problems of the novel. The main character of the novel Murat Kazybekov unexpectedly for himself reveals the existence of his twin, Marat, accidentally appearing at the celebration of his anniversary. Next to the jubilee man he sees his beloved Balzhan, with whom he parted in an absurd accident. 
The narrative in the novel M.Magauin is from the first person, i.e. from the mouth of the main hero Murat Kazybekov, who, after graduating from the institute, stays in graduate school, is engaged in research activities. After parting with Balzhan, Murat does not find happiness in family life. The only solace becomes a job for him. His wife leaves him, children acquire their families. While he alone lives in a small apartment, immersed in his labors, a meeting with Marat - a person successful, authoritative, surrounded by the attention of relatives and friends, is brewing.

By time Murat's split begins after graduation from the institute. Later, the hero realizes a strange memory - the feeling that gripped him that day, that he lost part of himself and became inferior. He was often visited by strange dreams in which he saw himself in the guise of two beings:

«Ойым онға емес, өзім екіге бөліндім.. Бүтін емес, жарты кісі сияқтымын» (Magauin, 2008: 42).

Researcher A.B. Mukhamedzhanova emphasizes that M. Magauin in the novel "Zharmak" raises to the philosophical generalization of modern reality in the postmodern image. Thus, using the theme of duality, split personality in the novel genre, the writer touches on the problem of adaptation in life (Mukhamedzhanova, 2009: 20).

Potentially bifurcation is one of the main complexes of the human psyche. Duality as a literary device has developed in Western and Russian literature. The paradigm of the inner duality of man, conditioned by alienation from his moral essence, became the leading one in the modern world literature. The collision of duality in Russian literature is associated with the name of F.M. Dostoevsky. In his texts the motive of repentance prevails, and suffering is seen as a path to purification. The duality complex in Western literature is reflected in the works of A. Camus, Z.Freud, C.-G. Jung, who, one way or another, formed the principles of the aesthetics of modernism. The motif of duality associated with the search for his hidden "I", the purpose of existence - to find the plane, a condition which can lead to the attainment of the original integrity of the inner "I".

In the contemporary literature of Kazakhstan, undoubtedly, attention is paid to the themes of works by writer, publicist, screenwriter Didar Amantay, one of the brightest representatives of the new wave in Kazakh literature. Some people write about him as a postmodernist, others - as a founder city literature. The heroes of his works are young people, educated, intelligent, looking for answers to the difficult issues of our time ("Flowers and Books", etc.). According to the figurative definition of G. Belger, "in prose he is a philosopher, in philosophy - a prose writer. Being perfectly oriented in the world classics and contemporary literature, freely changing from the comparison of images and motifs in national literatures to the analysis of Kazakh literature, D. Amantay is convincing in his conclusions. Essays emerging from the pen of D. Amatay, individual, unique and often permeated with sadness. The author is convinced that "everything is transitory, except for the senses" (Belger, 2007: 22).

"Flowers and Books" by D. Amantay is a complicated novel. According to the definition of Ph.D. A. Nauryzbaeva, this is an intellectual novel. Researcher L. Safronova refers genre specifics of this novel as a novel of associations. D. Amantay set himself the goal - to create a form that goes beyond the traditional framework. The volume of the novel is small, yet it is almost impossible to retell it briefly. A complex vision of the world, manifested in the works of contemporary writers, contributes to the process of transformation and an active search for new genre forms for the expression of complex, polyphonic, multi-dimensional conception of the world. In this aspect, we can talk about specific typological, artistic parallels between Kazakh literature and the world literature.

The novel tells the story of a young writer in the throes of creativity in the era of stagnation, revealed the world of his thoughts. With Alisher, we meet at the most difficult moment of his life, when money, career and love lose meaning to him, he is concerned only with one question: "Is there a God? ». In addition, the novel includes twenty-five laconic, independent in form and content poems. This reflects the bright philosophical orientation of the writer, so conditionally genre of the work can be described as intellectual and philosophical novel. Other genre designations in relation to this work, researchers did not offer. Apparently, this is due to the original composition of the 
novel, which requires further study.

In the novel there are many quotations from the sacred books - the Koran, the Bible. Alisher appeals to the spirit of his great ancestors Khutu, Uken, Batachi, Baru, Bukh, Chilbi and their glorious descendants - Maral, Kugaya, Batuna, Ogua, Baty, Otchy, Tau, Batygaya, Sembek, Bokuteya, Boroldaya and many others.

Unusual, extraordinary, original style highlights this work. Mean phrases convey the whole dramatic nature of Alisher's search, and exactly what he wanted to say, the hero lost the meaning of simple concepts. We have already noted above that modern writers often use simple and monosyllabic sentences, investing in them a meaningful sense. Thoughts of the author are transmitted as if by a dotted line, the rest should be thought out by the reader himself. Complex syntactic constructions are not so common in the works of writers of the new wave. The complex syntax in modern novels in mind the complexity and high volume is a problem for the reader, first of all - the perception of the problem. Many authors end the sentence in novels with an ellipsis.

Violation of the traditional rules of grammar, the emergence of writer's accosonalisms - the practice of new modernist literature. Unexpected and original interpretations of words reveal the contradictory essence of modern reality. This trend can be traced in the works of T. Abdikov, D. Nakipov, D. Amantay and many others.

As G.K. Belger points out, "the novel consists entirely of hints, reflections, incompleteness, torn narrative, random and strange cohesion-episodes, allusions of sacral texts, the bizarre encounters of the ancient Kipchak, Saka civilizations and the specifics of the modern metropolis, diachonium (displacement of time strata), the emotional throws of the young writer Alisher, who is looking for Tengri, who dreams to create the "Tengri Book", which evokes in his meditations the spirit of Jesus, Moses, Muhammad, Zarathushtra, Tao, Buddha, Confucius, ancient Turks, archangels and angels, representatives of Dark forces,, Now and then colliding with the realities of today's Kazakh poets, parties, gypsies, agents, friends and girls, Almaty's nightlife, etc. " (Belger, 2007: 22).

Peculiarity, unusualness, originality, avoiding the traditional forms of narrative in the prose of D. Amantay noted by many researchers, describing his style as a laconic, philosophical. The writer does not take a great interest in descriptions that correspond to the spirit of modernity, dottedly denotes a thought, allowing the reader to think out, to conjecture, to reflect, to sympathize. His prose is dynamic and associative. By the way of execution is technological.

Results. The novels of modern Kazakh literature are distinguished by the desire of writers to embrace reality in all its multifaceted and contradictory nature. Simultaneously there are classical forms of writing and non-traditional, cardinally changing compositional and structural-content modifications of the novel. Writers bring into the literature new themes and ideas, new "techniques" of writing and tricks, from a new angle view consider the existential problems of mankind. All this is most productively embodied in the genre of the novel. There has been a trend in which the novels of realism are gradually being replaced by contemporary modernist variants that bear signs of profound transformation.

Conclusion. "The literary phenomena of the last decade, consolidating the conquered, differ acute topicality of their subjects and problems, the historicism of thinking, the strengthening of communication, internal interdependence of psychologism and sociality, close attention to the character, The inner world of man, the national, moral and psychological aspects of such global problems as ecology, the consequences of urbanization, the achievements of the scientific and technological revolution..." - this is how Sh. Yeleukenov characterizes the period of independence in Kazakh literature. (Yeleukenov, 1984: 19).

Analysis of the works of contemporary writers of Kazakhstan reveals in their works postmodern phenomena, motives and traits. Oriental worldview, aesthetics, world outlook transform the stylistic traditions perceived from Western literature and set new parameters in national literature. The influence of postmodernism in the literature of Kazakhstan extends the genre typology of works of contemporary writers, transforms the novel, its genre content. 


\author{
Е. Султан \\ М.О.Әуезов атындағы Әдебиет және өнер институты, \\ жетекші ғылыми қызметкер, $\mathrm{PhD}$ доктор, \\ Алматы, Қазақстан \\ E-mail: yertaysultan@gmail.com \\ ORCID: 0000-0003-3240-2744
}

\title{
Қазіргі қазақ романдары: жанрлық трансформация
}

Түйін. Мақалада классикалық критерийлер шеңберінен шығып кеткен қазіргі романның формалары жан-жақты қарастырылып, талданады. Дәлірек айтсақ, Т.Әбдіковтің «Парасат майданы», М.Мағауин «Жармақ» және Д.Амантайдың «Гүлдер мен кітаптар» шығармалары негізінде қазіргі романның жанрлық модификациясына шолу жасалды. Аталған жазушылардың шығармаларын талдау арқылы әрбір автордың өмір шындығын берудегі өзіндік әдіс-тәсілдері мен техникалық ерекшеліктері анықталды. Осылайша, Т.Әбдіков өзі суреттеп отырған әлемге шынайылық иллюзиясын беру үшін күнделіктің «ғабадаттық», «рефлективтік» қасиетін ескере отырып, баяндау тәсілін, ал М.Мағауин батыс әдебиетінде А.Камю шығармашылында, 3. Фрейд, К.-Г. Юнг зерттеулерінде көтерілген екідайлылық парадигмасын қолданады. Осы арқылы постмодернистік бейнелеудегі қазіргі шынайылықты философиялық жалпылыққа дейін көтереді. Д.Амантай толықтай дәстүрлі баяндау формасынан алыстап, қазіргі өмір бейнесінің қарама-қайшылығын ашуға тырысады.

Кілтті сөздер: қазіргі қазақ прозасы, роман, жанрлық модификация, роман трансформация

\section{Султан Е.}

Институт литературы и искусства им. М.О. Ауэзова ведущий научный сотрудник, доктор $\mathrm{PhD}$,

Алматы, Казахстан

E-mail: yertaysultan@gmail.com

ORCID: 0000-0003-3240-2744

\section{Современные казахские романы: жанровая трансформация}

Резюме. В статье рассматриваются и анализируются современные романные формы, которые вышли за пределы классических критериев. В частности, по произведениям таких авторов, как Т.Абдиков «Парасат майданы», М.Магауин «Жармак» и Д.Амантай «Гулдер мен Китаптар» определена жанровая модификация современного романа. В результате анализа произведений современных писателей выявлены своеобразные приемы и техника передачи современной действительности каждым автором. Так, Т.Абдиков прибегает к дневниковому повествованию, используя в художественных целях его «исповедальную», «рефлективную» функцию, которая способствует раскрытию характера и создает иллюзию достоверности и правдивости изображенной реальности, а М.Магауин использует парадигму двойничества, отраженного в западной литературе в произведениях А. Камю, в трудах 3. Фрейда, К.-Г. Юнга. Таким образом, М.Магауин поднимается до философского обобщения современной действительности в постмодернистском изображении. Д.Амантай полностью уходит от традиционных форм повествования, старается раскрыть противоречивую сущность современной действительности. 


\section{Ключевые слова: современная казахская проза, романы, жанровая модификация, трансформация романа.}

\section{Information about authors:}

Sultan Y., M.O. Auezov Institute of Literature and Art, Leading researcher, PhD, Almaty, Kazakhstan. E-mail: yertaysultan@gmail.com. Scopus ID: 57192096203. WoS ID: D-8572-2015. Spin-code: 6055-8410. ORCID ID: 00000003-3240-2744

[1] Abdikov T. (2003). Parasat Maidany. Astana: Foliant (kaz).

[2] Amantay D. (2003). Gulder man kitaptar. Novel. Almaty (kaz).

[3] Bakhtin M.M. (1979) Problems of Dostoevsky's poetics. Moscow (kaz).

[4] Belger G.K. (2007) "Flowers and books of Didar." On the work of D. Amantay. Let's start with Monday. 18 (680), 11-17 (rus).

[5] Ishanova A.K. (2005) Typology of the literary game from baroque to postmodernism. Astana (rus)

[6] Kaliyeva A., Sultan Y. (2017). National and universal values in modern Kazakh novels. World of science, culture, education (RISC). 6 (67), 537- 539 (rus).

[7] Madibaeva, K., Alkebaeva, D., Sultan Y. (2014). Magzhan Zhumabaev and spiritual ecology. Procedia - Social and Behavioral Sciences (Web of Science), Vol. 114, 515-518 (eng)

[8] Magauin M. (2008). Zharmak. Novels . Zhambyl (kaz)

[9] Mukhamedzhanova A.B. (2009). New prose of Mukhtar Magauin: the author's abstract ... cand. Philol. Sciences: 10.01.02. Almaty. (kaz)

[10] Sultan Y. (2016). Main directions of the modern transformation of the novel. Science and Life in Kazakhstan. 3 (38), 185-190 (kaz)

[11] Sultan Y., Alkebaeva D., Kurkebayev K., Abdikulova R., Sagyndykov N. (2016). The categories of time and space in modern novel transformation. Man in India(Scopus), Vol. 96, Issue 10, 3927-3937 (eng)

[12] Yeleukenov Sh.R. (1984) To the question of the genre originality of the Kazakh novel. Prostor. 11, 181-188 (kaz)

\section{ӘДЕБИЕТ}

[1] Әбдіков Т. Парасат Майданы. - Астана: Фолиант, 2003 (қаз).

[2] Амантай Д. Гүлдер мен кітаптар. Роман. - Алматы, 2003 (қаз).

[3] Бахтин М.М. Достоевский поэтикасының мәселелері. - Мәскеу, 1979 (қаз).

[4] Бельгер Г.К. «Дидардың гүлдері мен кітаптары». Д.Амантайдың шығармашылығы туралы. // Дүйсенбіден бастайық. 2007. - 18 (680). - 11-17 (орыс).

[5] Ишанова А.К. Бароккадан постмодернизмге дейінгі әдеби ойын типологиясы. - Астана, 2005 (орыс)

[6] Қалиева А., Султан Е. Қазіргі қазақ романдарындағы ұлттық және жалпыадамзаттық құндылықтар. // Ғылым, мәдениет, білім әлемі (RISC). - 2017. - 6 (67) - 537-539 (орыс).

[7] Мадибаева, К., Әлкебаева, Д., Султан Е. Мағжан Жұмабаев және рухани экология. // Жинақ - әлеуметтік және психология ғылымдары (Web of Science). - 2014. - том. 114 - 515-518 (ағыл.)

[8] Мағауин М. Жармақ. - Роман. Жамбыл, 2008 (қаз)

[9] Мұхамеджанова А.Б. Мұхтар Мағауиннің жаңа прозасы: авторефераты ... канд. Филол. Ғылымдар: 10.01.02. - Алматы, 2009 (қаз)

[10] Султан Е. Қазіргі роман трансформациясының негізгі бағыттары. // Қазақстан ғылымы және өмірі. - 2016. - 3 (38). 185-190 (қаз)

[11] Султан Ю., Алкебаева Д., Күркебаев К., Әбдіқұлова Р., Сағындықов Н. Қазіргі роман трансформациясындағы уақыт пен кеңістік категориялары. // Man in India (Scopus). - 2016. - том. 96, № 10. - 3927-3937 (ағыл.)

[12] Елеукенов Ш.Р. Қазақ романының жанрлық ерекшелігі туралы. // Простор. -1984. - 11. - 181-188 (қаз).

\section{ЛИТЕРАТУРА}

[1] Абдиков Т. Парасат Майданы. - Астана: Фолиант, 2003 (каз).

[2] Амантай Д. Цветы и книги. Роман. - Алматы, 2003 (каз).

[3] Бахтин М.М. Проблемы поэтики Достоевского. - Москва, 1979 (каз).

[4] Белгер Г.К. "Цветы и книги Дидар". // О творчестве Д. Амантая. Начнем с понедельника. - 2007. - 18 (680) - С. 11-17 (pycc.).

[5] Ишанова А.К. Типография литературной игры от барокко до постмодернизма. - Астана, 2005. (русс.)

[6] Калиева А., Султан Ю. Национальные и общечеловеческие ценности в современных казахских романах. // Мир науки, культуры, образования (РИНЦ). - 2017. - 6 (67). - 537-539 (русский).

[7] Мадибаева К., Алкебаева Д., Султан Ю. Магжан Жумабаев и духовная экология. // Сборник - Социальные и психологические науки. - 2014. - Vol. 114. - С. 515-518 (англ.)

[8] Магауин М. Жармак. Романы. - Жамбыл, 2008 (каз)

[9] Мухамеджанова А. Новая проза Мухтара Магауина: автореферат ... канд. филол. наук. Наук: 10.01.02. - Алматы, 2009. (Каз)

[10] Султан Е. Основные направления современной трансформации романа. Наука и жизнь Казахстана. - 2016. - 3 (38). 185-190 (каз)

[11] Султан Ю., Алкебаева Д., Куркебаев К., Абдикулова Р., Сагындыков Н. (2016). Категория времени и пространство в трансформацияи современного романа. // Man in India (Scopus). - Vol. 96, выпуск 10 - С. 3927-3937 (англ)

[12] Елеукенов Ш.Р. К вопросу о жанровой самобытности казахского романа. // Простор. - 1984. - 11. - С. 181-188 (каз) 
